\title{
AVIAN SPECIES COMPOSITION PROFILE AND FEEDING GUILDS UNDER THE AEROBIC RICE FIELD
}

\author{
Badrulhadza Amzah', Razali Baki ${ }^{2}, \&$ Mohd Hafizi Yahya ${ }^{3}$ \\ ${ }^{1}$ Paddy \& Rice Research Center, Malaysia Agricultural Research and Development Institute (MARDI), Malaysia \\ Persiaran MARDI-UPM Serdang Selangor 43400 \\ ${ }^{2}$ Center for Agriculture and Bioscience International (CABI), Malaysia \\ Persiaran MARDI-UPM Serdang Selangor 43400 \\ ${ }^{3}$ Promotion \& Business Development Center, MARDI Cherating, Malaysia \\ Kuantan-Kemaman KM 35 Kuantan Pahang 26100 \\ E-mail: bhadza@mardi.gov.my
}

Manuscript received: 21 January 2021. Revision accepted: 22 February 2021.

\begin{abstract}
Avian species composition profile and feeding guilds under the aerobic rice field. In Malaysia, the aerobic rice production system is an alternative approach to growing rice in a water-scarce environment. Like irrigated rice, aerobic rice also can sustain a diversity of avian fauna. The current status of birds in the rice fields of Malaysia especially under aerobic rice condition has not been widely researched. Therefore, this study aims to document the richness, diversity and feeding guilds of bird species in aerobic rice cultivation area. Birds were sampled and recorded using four randomly set up mist net at an upscaling aerobic rice plot in Serdang, Selangor during a period of the one month starting from the milky stage of the plant (75 days after emergence) until two weeks after harvest. 139 birds representing 11 species belonging to 7 families were recorded in the aerobic rice plot. The most abundant bird family observed was Estrildidae (80.58\%), followed by Hirundinidae (6.47\%), and Meropidae and Motacillidae (both recorded 5.04\%). Scaly-breasted munia (50.36\%) and white-headed munia (28.06\%) are the most abundant birds, while other types of munia such as chestnut munia and white-rumped munia are present in small numbers. Munias were the most observed bird species number (36.36\%) and therefore can be considered as the main avian pest of aerobic rice. The diversity indices, The Shannon-Wiener Index was 1.43 while The Reciprocal Simpson Index was 2.93. The richness index (The Margalef Index) was 2.03. The Equitability Index was 0.59. In term of feeding guild, most species belong to insectivore $(45.45 \%)$ and granivore $(36.36 \%)$ while the rest were piscivore/insectivore and granivore/insectivore. However, the granivore recorded the highest number of individuals (112 or 80.58\%) compared to other guilds. Presence of a relatively high diversity of bird species with varieties of feeding guilds indicated that aerobic rice does provide an attractive habitat or foraging site for avian fauna.
\end{abstract}

Key words: aerobic rice, bird species, diversity, feeding guilds, species composition

\section{INTRODUCTION}

Rice is the most important food crop grown in Malaysia (Vengedasalam et al., 2011). Rice is a highly protected crop in a strategically important industry in Malaysia (Daño \& Samonte, 2005). The country produces about 2 million tons of paddy rice annually and it is mainly cultivated under irrigated lowland condition. Currently, irrigated lowland rice is considered the most important ecosystem for rice production. Eight major granary areas have been reserved solely for irrigated rice cultivation where new rice varieties and new technologies from R\&D efforts are currently being adopted (Yahya, 2001).

According to Othman et al. (2014a), irrigated rice consume lots of water (1200-1500 mm per season) which is fast becoming scarce even in humid countries such as Malaysia. The increasing water demand from domestic and industrial sectors, decreasing quality and resources, is envisaged to cause a decline in water availability and threaten the sustainable production of irrigated rice production. In coping this situation, Malaysia Agricultural Research and Development Institute (MARDI) has introduced an aerobic rice variety which is currently the best alternative system for rice production in this fast-changing environment. Aerobic rice is meant to reduce water usage in rice production (Bouman, 2001). Saving of water under aerobic rice cultivation is achieved by eliminating continuous seepage and percolation, reducing evaporation and eliminating wetland preparation (Othman et al., 2014b). Yahya (2001) suggested that the none-granary rice areas are 
free to choose alternative crops for every season as irrigated rice cannot grow during the off-season due to lack of water supply. Aerobic rice is a good alternative to grow in these areas to boost rice production. In an aerobic rice production system, a relatively high yielding rice variety such as MRIA 1 (developed by MARDI), which can withstand substantial dry soil condition is grown under aerobic soil condition with some supplementary irrigation (Othman et al., 2014a).

According to Dhindsa \& Saini (1994), birds constitute an important component of agroecosystems and bird community in agricultural lands is characterized by over dominance of only a few granivorous and omnivorous species. Birds are generally acknowledged as pests in rice fields in Asia (FAO, 1973) but in Malaysia, little effort has been done toward understanding this problem (Avery, 1979). The current status of birds in the ricefields of Malaysia has not been properly researched except for a few isolated study (Sah et al., 2008). Azman et al. (2014), studied diversity and temporal distribution of birds in irrigated rice-growing areas in the Northern part of Peninsular Malaysia. However, no studies on avian fauna have been reported to-date in aerobic rice conditions. Further research in this area is needed to gather valuable information not only on the natural history of the avian fauna but also their relation to the aerobic rice cultivation.
Therefore, this study aims to document the bird species richness, diversity and feeding guilds in aerobic rice cultivation areas. New information regarding the potential avian pest, beneficial and protected avian fauna will be obtained. This information can then be used to further study avian fauna biology and ecology which in turn will assist in developing better management strategies when growing aerobic rice.

\section{MATERIALS AND METHODS}

Research Site. Bird surveys were conducted at aerobic rice upscaling plot in MARDI Headquarters, Serdang, Selangor, Malaysia at coordinates $2^{\circ} 59^{\prime} 25.7^{\prime \prime}$ N, 101 $41^{\prime} 36.0^{\prime \prime}$ E (Figure 1). The study site covered an area of 3 ha. The aerobic rice plot is surrounded by several habitat types such as coconut nursery plot, durian orchards and secondary forest. The study was conducted in July 2017 for the duration of 3 months.

Procedures. Trapping and collection of birds were done using four randomly set up mist net $(1 \times 3 \mathrm{~m})$ in a period of one month starting from the milky stage of the aerobic rice plant ( 75 days after emergence) until two weeks after harvest. The mist nets were fixed and stretched between two stick poles and placed at the aerobic rice field plot and nearby areas such as forest edge and open

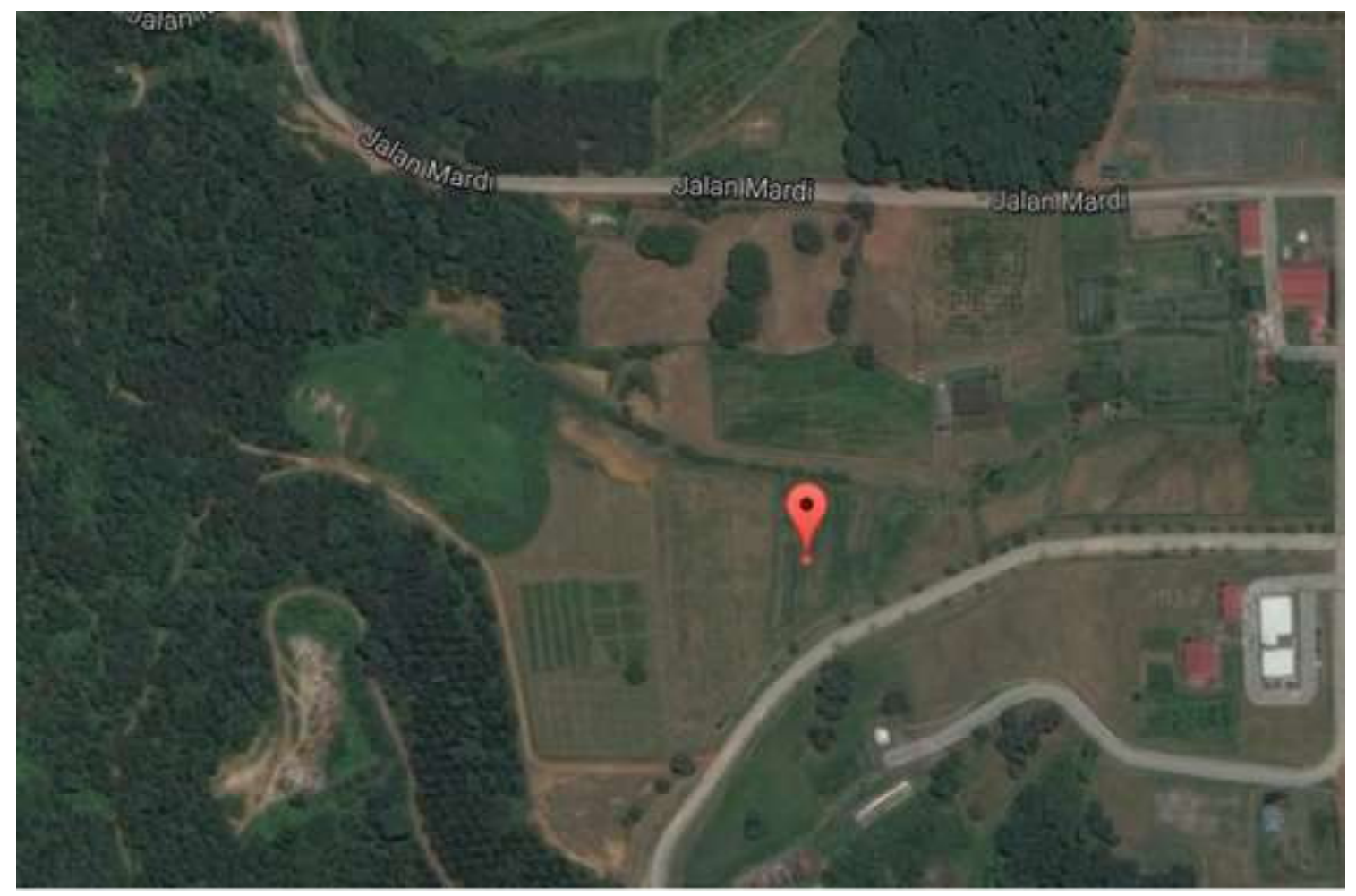

Figure 1. Location of study site at MARDI Headquarters, Serdang, Selangor, Malaysia. 
fields. The number of avian species trapped was counted and photographed for identification purpose. Traps were checked hourly at 09.00 hours and 16.00 hours to remove captured birds. Identification was based on the standard field guide and/or bird's websites. Feeding guilds of bird species was based on the observed feeding behaviour (Zakaria et al., 2009; Hassan-Aboushiba et al., 2011).

Data Analysis. Diversity, population density and species richness were determined using selected indices, namely; Shannon-Wiener Index, H, Reciprocal Simpson Index, D, Margalef Index, DM and Equitability Index, EH. The calculation was based on field sampling record. The indices are listed below:

$\begin{array}{ll}\text { Shannon-Wiener Index, } \mathrm{H} & =-\left(\sum \mathrm{Pi} \ln \mathrm{Pi}\right) \\ \text { Reciprocal Simpson Index, D } & =1 / \sum \mathrm{Pi}^{2} \\ \text { Margalef Index, } \mathrm{D}_{\mathrm{M}} & =(\mathrm{S}-1) / \ln (\mathrm{N}) \\ \text { Equitability Index, } \mathrm{E}_{\mathrm{H}} & =-\left(\sum \mathrm{Pi} \ln \mathrm{Pi}\right) / \ln (\mathrm{N})\end{array}$

$\mathrm{S}=$ Number of species;

$\mathrm{n}=$ number of individuals;

$\mathrm{N}=$ Total number of individuals;

$\mathrm{Pi}=\mathrm{n} / \mathrm{N}$

\section{RESULTS AND DISCUSSION}

Throughout the one month of sampling, 139 individual birds were recorded in the aerobic rice area. Eleven bird species from seven different families were recorded in the study area during the survey period (Table 1). Scaly-breasted munia, Lonchura punctulata was observed abundantly with the highest record of 70 individuals $(50.36 \%)$. This was followed by the whiteheaded munia, Lonchura maja, with a total of 39 individuals $(28.06 \%)$. Other species of munias included the chestnut munia, Lonchura atricapilla and the whitebreasted munia, Lonchura striata (Figure 2).

These four bird species fall under the Estrildidae family, which recorded the highest individual numbers $(80.58 \%)$. This was then followed by Hirundinidae (6.47\%), Meropidae and Motacillidae (both recorded

Table 1. Bird species recorded in the aerobic rice field at MARDI Serdang, Selangor

\begin{tabular}{|c|c|c|c|c|}
\hline No. & Bird species & Family & Number of individuals (n) & Feeding guild \\
\hline 1 & $\begin{array}{l}\text { Lonchura striata } \\
\text { (White breasted munia) }\end{array}$ & Estrildidae & 1 & Grainivore \\
\hline 2 & $\begin{array}{l}\text { Lonchura punctulata } \\
\text { (Scaly breasted munia) }\end{array}$ & Estrildidae & 70 & Grainivore \\
\hline 3 & $\begin{array}{l}\text { Lonchura atricapilla } \\
\text { (Chesnut munia) }\end{array}$ & Estrildidae & 2 & Grainivore \\
\hline 4 & $\begin{array}{l}\text { Lonchura maja } \\
\text { (White headed munia) }\end{array}$ & Estrildidae & 39 & Grainivore \\
\hline 5 & $\begin{array}{l}\text { Anthus rufulus } \\
\text { (Paddyfield pipit) }\end{array}$ & Motacillidae & 7 & Insectivore \\
\hline 6 & $\begin{array}{l}\text { Merops philippinus } \\
\text { (Blue tailed bee eater) }\end{array}$ & Meropidae & 7 & Insectivore \\
\hline 7 & $\begin{array}{l}\text { Halcyon smyrnensis } \\
\text { (White throated kingfisher) }\end{array}$ & Halcyonidae & 2 & Piscivore/insectivore \\
\hline 8 & $\begin{array}{l}\text { Collocalia esculenta } \\
\text { (Glossy swiflet) }\end{array}$ & Apopodidae & 1 & Insectivore \\
\hline 9 & $\begin{array}{l}\text { Crecopsis daurica } \\
\text { (Red rumped swallow) }\end{array}$ & Hirundinidae & 1 & Insectivore \\
\hline 10 & $\begin{array}{l}\text { Hirundo rustica } \\
\text { (Barn swallow) }\end{array}$ & Hirundinidae & 8 & Insectivore \\
\hline 11 & $\begin{array}{l}\text { Turnix suscitator } \\
\text { (Barred button quail) }\end{array}$ & Turnicidae & 1 & Grainivore/insectivore \\
\hline
\end{tabular}




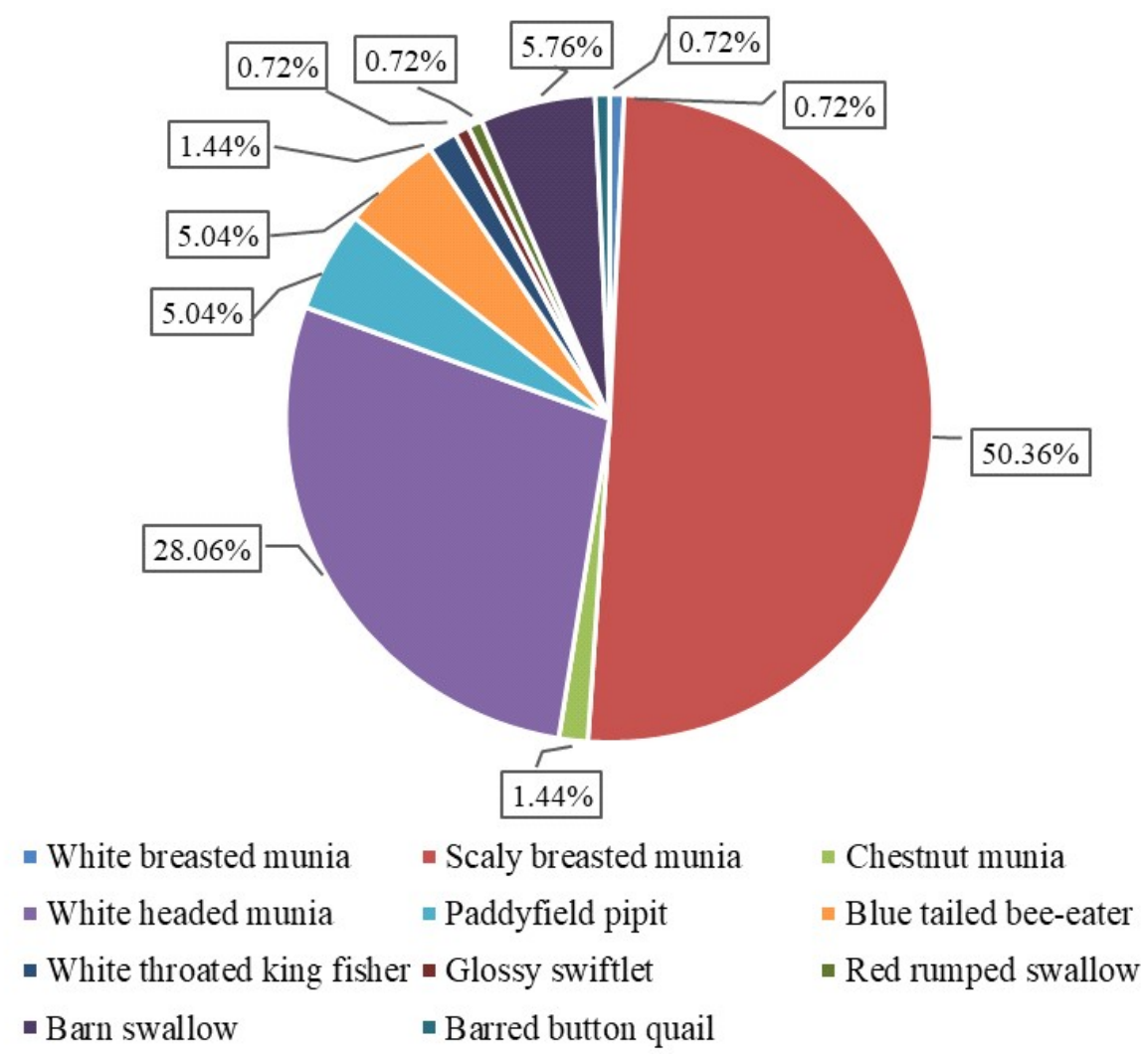

Figure 2. Bird species composition of the aerobic rice field at MARDI Serdang, Selangor.

$5.04 \%$ ) families (Figure 3). Out of 11 species, Estrildidae had the highest number of species observed (36.36\%) (Figure 4). Similar results were obtained by Azman et al. (2014), where high numbers of munia were recorded in irrigated ricefield especially during the growing period of the rice plant. In her study, she carried out her first observation at 70 days after sowing (DAS) and recorded 27 individuals of $L$. striata. She also recorded other species of granivorous birds such as the eurasian tree sparrow, Passer montanus and the baya weaver, Ploceus philippinus as well as L. punctulata, L. atricapilla and L. maja $72.73 \%$ of the bird species found in the aerobic rice area in this study relate to the results obtained in Azman et al. (2014), indicating that both environments can sustain similar bird species (Table 2). The main difference in the composition lies in the fact that the avian fauna related to the aquatic environment is less prominent in the aerobic rice environment. Several species of waterbirds found in irrigated rice field areas as recorded by Azman et al. (2014), were less noticeable in the aerobic rice plot.

Based on the value of the diversity indices, Reciprocal Simpson Index, D and Shannon-Wiener Index, $\mathrm{H}$, it can be inferred that the bird diversity in the aerobic rice area during the study period is low. Both indices recorded the value of 2.93 and 1.43 , respectively (Table 3). The value of Reciprocal Simpson Index starts with 1 as the lowest possible figure which represents a community containing only one species. In this study, the total number of species observed was 11 . A value of 2.93 reflects that the avian fauna in the study area is less diverse. As for the Shannon-Wiener Index, the low value also indicates low diversity. For example, a community with only one species would have an $\mathrm{H}$ value of 0 . Based on the calculation, this index produced a value of 1.43 which is relatively close to the value 0 . Also, the low diversity in the avian fauna is reflected in the fact that the community was dominated by only two species which were the Scaly-breasted munia and the White-headed munia. This is revealed by the low value of Equitability Index, EH and Margalef Richness Index, DM which indicate low species evenness and richness. The Equitability Index was 0.59 and the Margalef Index was 2.03 (Table 3).

In term of feeding guilds, the avian fauna observed in the aerobic rice area can be placed under four categories, namely granivore, insectivore, piscivore/ insectivore and granivore/insectivore. Munias were the most observed bird group because they are the main 


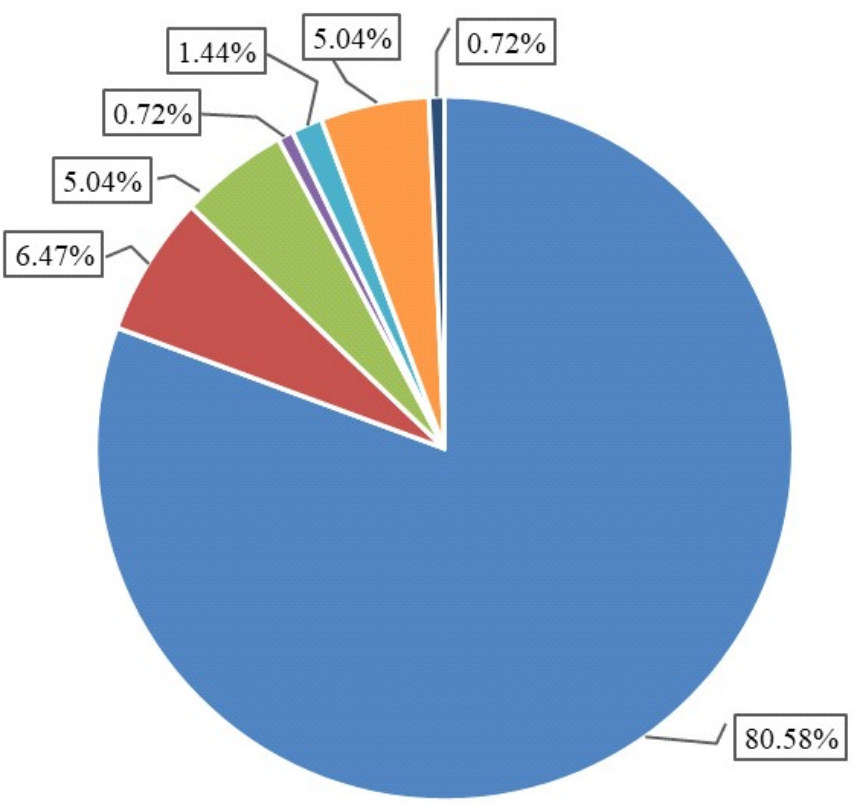

- Estrildidae $\quad$ Hirundinidae $=$ Motacillidae $=$ Apopodidae

- Halcyonidae $=$ Meropidae - Turnicidae

Figure 3. Percentage of individual numbers based on bird family observed in the aerobic rice field at MARDI

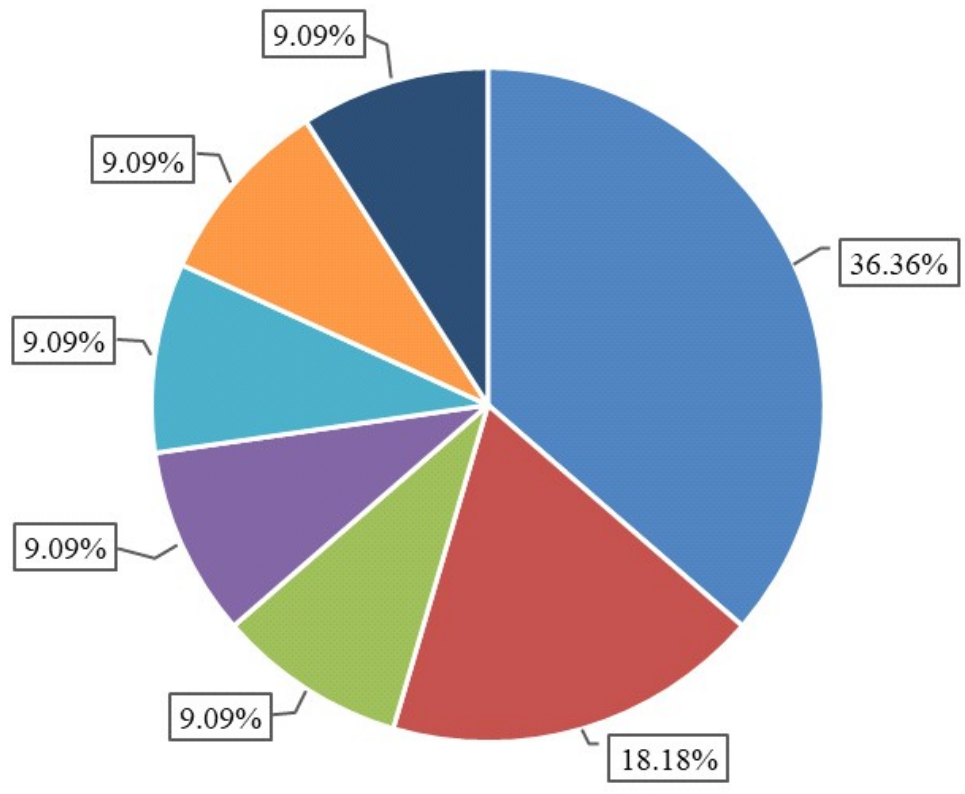

$$
\begin{aligned}
& \text { - Estrildidae } \quad \text { - Hirundinidae }=\text { Motacillidae }=\text { Apopodidae } \\
& \text { " Halcyonidae }=\text { Meropidae } \quad \text { - Turnicidae }
\end{aligned}
$$

Figure 4. Percentage of species numbers based on bird family observed in the aerobic rice field at MARDI Serdang, Selangor. 
avian pest of aerobic rice (grainivore) (Table 1). They recorded the highest number of individuals (112 or $80.58 \%$ ) followed by insectivore (24 or $17.27 \%$ ) (Figure $5)$. Avery (1979) reported that there are several granivorous bird species which are potential pests to rice in Malaysia. In his study, he suggested that genus Lonchura such as L. striata, L. leucogastra, L. punctulata, L. malacca and L. maja are the potential pest to the irrigated ricefields.
In aerobic rice, severe attack of birds was observed in small-scaled secondary or mini rice granary areas, water shortage areas, idle land, favourable uplands and rainfed areas which are normally isolated. Birds cause damage to the plant by attacking rice grains on rice panicle during milk stage until the ripening stage of the crop. According to Othman et al. (2015), pests of aerobic rice includes insect pests such as rice stem borers, rice stink bugs, rice leaf folders, rice field rats

Table 2. Comparison of bird species observed in two different rice ecosystems

\begin{tabular}{|c|c|c|}
\hline No. & Bird species observed in aerobic rice field & Observed by Azman et al. (2014) in irrigated rice field \\
\hline 1 & $\begin{array}{l}\text { Lonchura striata } \\
\text { (White breasted munia) }\end{array}$ & Yes \\
\hline 2 & $\begin{array}{l}\text { Lonchura punctulata } \\
\text { (Scaly breasted munia) }\end{array}$ & Yes \\
\hline 3 & $\begin{array}{l}\text { Lonchura atricapilla } \\
\text { (Chesnut munia) }\end{array}$ & Yes \\
\hline 4 & $\begin{array}{l}\text { Lonchura maja } \\
\text { (White headed munia) }\end{array}$ & Yes \\
\hline 5 & $\begin{array}{l}\text { Anthus rufulus } \\
\text { (Paddyfield pipit) }\end{array}$ & Yes \\
\hline 6 & $\begin{array}{l}\text { Merops philippinus } \\
\text { (Blue tailed bee eater) }\end{array}$ & Yes \\
\hline 7 & $\begin{array}{l}\text { Halcyon smyrnensis } \\
\text { (White throated kingfisher) }\end{array}$ & Yes \\
\hline 8 & $\begin{array}{l}\text { Collocalia esculenta } \\
\text { (Glossy swiflet) }\end{array}$ & No \\
\hline 9 & $\begin{array}{l}\text { Crecopsis daurica } \\
\text { (Red rumped swallow) }\end{array}$ & No \\
\hline 10 & $\begin{array}{l}\text { Hirundo rustica } \\
\text { (Barn swallow) }\end{array}$ & Yes \\
\hline 11 & $\begin{array}{l}\text { Turnix suscitator } \\
\text { (Barred button quail) }\end{array}$ & No \\
\hline
\end{tabular}

Table 3. Value of biodiversity indices for bird species and numbers found in during the study

\begin{tabular}{|c|c|}
\hline Parameter and indices & Value \\
\hline $\mathrm{S}$ (number of species) & 11 \\
\hline N (total number of individuals) & 139 \\
\hline $\mathrm{P}_{\mathrm{i}}=\mathrm{n} / \mathrm{N}$ & \\
\hline$\sum(\operatorname{sum})$ of $\mathrm{P}_{\mathrm{i}}^{2}$ & 0.3414 \\
\hline$\sum($ sum $)$ of $P_{i} \ln P_{i}$ & -1.4312 \\
\hline $\mathrm{H}$ (Shannon Index $)-\left(\sum \mathrm{Pi} \ln \mathrm{Pi}\right)$ & 1.4312 \\
\hline H (Shannon Index $)-\left(\sum\right.$ Pi log Pi) & -0.6217 \\
\hline D (Reciprocal Simpson Index) $1 / \sum \mathrm{Pi} 2$ & 2.9291 \\
\hline $\mathrm{D}_{\mathrm{M}}($ Margalef Richness Index) $(\mathrm{S}-1) / \mathrm{Ln}(\mathrm{N})$ & 2.0266 \\
\hline $\mathrm{E}_{\mathrm{H}}($ Equitability Index $)-\left(\sum \mathrm{Pi} \ln \mathrm{Pi}\right) / \mathrm{Ln}(\mathrm{N})$ & 0.5969 \\
\hline
\end{tabular}


and avian pests. From observations, the threat posed by avian pests or birds seems to be much greater as aerobic rice is usually cultivated in isolated and small-scaled nongranary areas. Damage caused by other types of pests is less serious in aerobic rice condition.

There were five species of insectivorous birds observed during the survey period (45.45\%) (Figure 6). The insectivorous birds present were found to be foraging on the insects that were considered as aerobic rice insect pests such as the rice bugs, Leptocorisa spp., and grasshoppers (Conocephalus longipennis and Oxya spp.). These birds especially the swallows and swiftlets could act as good biological control agents assisting in reducing yield loss caused by the insect pests.

Even though aerobic rice field in MARDI Serdang showed low diversity of avian fauna, presence of several bird species with a variety of feeding guilds indicated that aerobic rice provides an attractive habitat or foraging site for avian fauna. Throughout the one month of sampling, the aerobic rice field and the surrounding areas at MARDI Serdang were identified as ideal habitats for several bird species. Further studies need to be carried out to further substantiate and strengthen the results obtained in this study and to acquire a comprehensive avian fauna profile under aerobic rice cultivation. Regardless, this study managed to obtain the groundwork and the first attempt to obtain a piece of basic information on avian fauna density and diversity in aerobic rice habitat. Besides, information regarding potential avian pest and beneficial avian species were also obtained. The knowledge gained here can be used as the basic platform to carry out further avian biology and ecology studies on which may have significant economic importance as they can be utilized in proper planning and efficient management of aerobic rice. Information on birds' status and population estimation also can contribute to conservation efforts and in developing sustainable wildlife management. This study reveals that three bird species, namely, Halcyon smyrnensis (white-throated kingfisher), Merops philippinus (blue-tailed bee-eater) and Hirundo rustica (barn swallow) are currently listed as endangered and protected by the law.

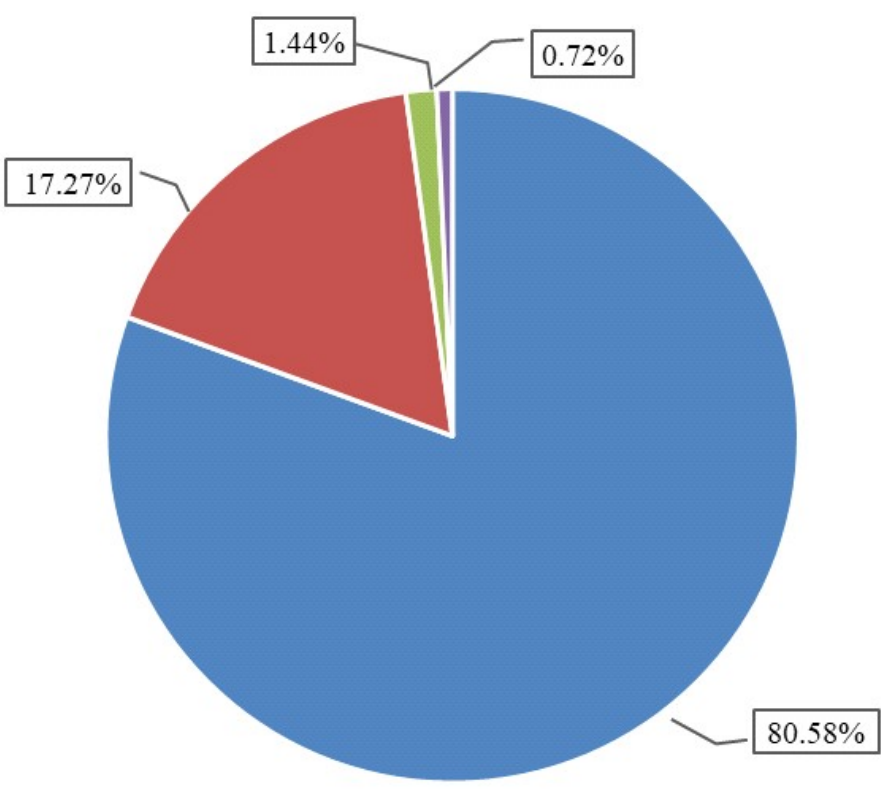

- Granivore "Insectivore $\quad$ Piscivore/insectivore " Granivore/insectivore

Figure 5. Percentage of individual numbers based on bird feeding guild observed in the aerobic rice field at MARDI Serdang, Selangor. 


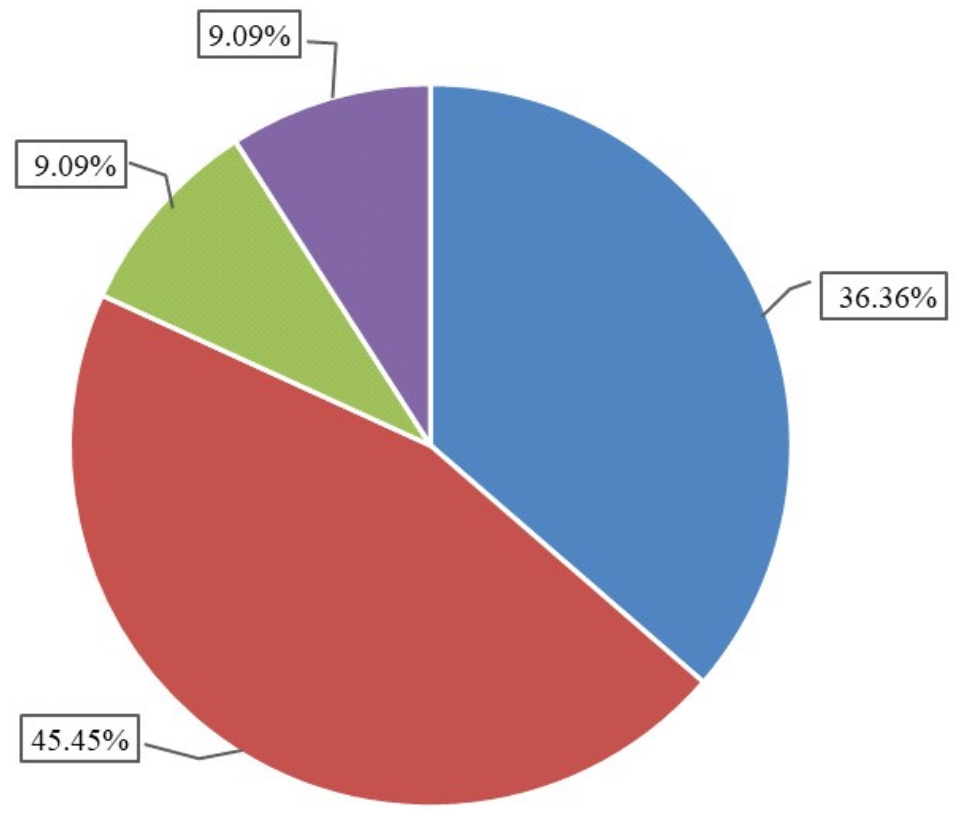

- Granivore $\quad$ Insectivore $\quad$ Piscivore/insectivore $\quad$ Granivore/insectivore

Figure 6. Percentage of species numbers based on bird feeding guild observed in the aerobic rice field at MARDI Serdang, Selangor.

\section{CONCLUSION}

There are several documented studies on avian species profile in the irrigated rice field environment. However, in a different agronomic condition such as aerobic cultivation, only a few are available, and this study was the first attempt in documenting the avian diversity in such area. Profiles for both rice ecosystems were almost the same. In this study, it can be concluded that aerobic rice ecosystem basically showed low biodiversity and this environment was mostly dominated by bird species from the grainivore feeding guild. This was based on the highest individual numbers observed. Most of the species was pest of aerobic rice. Further study needs to be done especially in terms of this avian pest impact on the yield production and how to have a good management practice in protecting the crop.

\section{ACKNOWLEDGMENTS}

This work was supported by Malaysian Agriculture Research and Development Institute (MARDI) (10th Malaysia Plan (RMK10) Mega Project 21003001390001-2015B at MARDI).

\section{REFERENCES}

Avery ML. 1979. Food preferences and damage levels of some avian rice field pests in Malaysia. In: Jackson WB, Jackson SS, \& Jackson BA (Eds.). Bird Control Seminars Proceedings. pp. 161166. University of Nebraska, Lincoln.

Azman NM, Latip S, Anuar S, Mohd MA, Muin MA, Ahmad AB, \& Shafie NJ. 2014. Diversity and temporal distribution of birds in rice-growing landscape, Northern Peninsular Malaysia. Sains Malays. 43(4): 513-520.

Bouman B. 2001. Water-efficient management strategies in rice production. Int. Rice Res. Notes. 26(2): $17-22$.

Daño EC \& Samonte ED. 2005. Public sector intervention in the rice industry in Malaysia. Southeast Asia Regional Initiatives for Community Empowerment (SEARICE).

Dhindsa MS \& Saini HK. 1994. Agricultural ornithology: an Indian perspective. J. Biosci. 19(4): 391-402.

FAO. 1973. Vertebrate pest management in Asia and the Far East. FAO publ. RAFE 14. Bangkok. 
Hassan-Aboushiba AB, Ramli R, \& Sofian-Azirun M. 2011. Species composition and feeding guilds of birds utilizing palm oil mill effluent (POME) area in Carey Island, Malaysia. In: Wu RC (Ed.). 2nd International Conference on Environment Science and Technology Volume 6. pp. 28-31. IACSIT Press, Singapore.

Othman S, Hussain ZPMD, Sheng CC, Man A, Ahmad R, \& Amzah B. 2014a. Padi aerob untuk mengatasi masalah kekurangan air. J. Teknol. 70(6): 65-68.

Othman S, Sheng CC, Man A, Zainudin H, Amzah B, Ahmad R, Mohd Fitri M, Allicia J, Mohd Khusairy K, Sulaiman SA, \& Rosnani H. 2014b. Aerobic rice: More rice with less water. Brussels Innova 2014. 13-15 November 2014. Brussels.

Othman S, Man A, Sheng CC, Amzah B, Khusairy M, Fitri MM, Allicia J, Rosnani H, \& Sulaiman SA. 2015. Manual Padi Aerob. MARDI, Serdang. Malaysia.
Sah ASRM, Mansor M, Shah SAM, Rawi CSM, Ahmad AH, \& Jaafar I. 2008. Agrobiodiversity of muda rice agroecosystem: a case study in largest granary area of Malaysia. Wetland Science. 6(1): 34-44.

Vengedasalam D, Haris M, \& MacAulay G. 2011. Malaysia rice trade and government interventions. Contributed paper presented to the $55^{\text {th }}$ Annual Conference of the Australian Agricultural and Resource Economics Society. Melbourne.

Yahya TMBT. 2001. Crop diversification in Malaysia. http://www.fao.org/3/X6906E/x6906e08.htm. Accessed on 20 January 2021.

Zakaria M, Rajpar MN, \& Sajap AS. 2009. Species diversity and feeding guilds of birds in Paya Indah Wetland Reserve, Peninsular Malaysia. Int. J. Zool. Res. 5(3): 86-100. 